\title{
ORNAMENTA SUNT ISTA NON VINCULA - A PARADOXICAL REEVALUATION OF THE INSTRUMENTS OF TORMENT IN THE EARLY CHRISTIAN MARTYROLOGICAL LITERATURE
}

From the very beginning ancient Christians perceived death for Christian religion as an ideal of the imitation of Christ (imitatio Christi). Those who died for their faith were considered to be Christians par excellence, true witnesses ( $\mu \alpha \dot{\alpha} \tau \tau \nu \rho \varepsilon \varsigma$ ) of the resurrected Christ. In the Graeco-Roman world, where man was first of all defined as "mortal" ( $\theta v \eta \tau$ cós, mortalis) and gods as "immor-

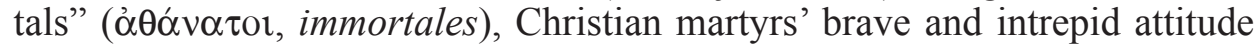
towards death, which questioned its power over human nature, was noticed and, albeit with reservation, marveled at also by pagans ${ }^{1}$.

The Christian's death, however, is in its essence something more than a mere negation of human mortality, more than a "negative theophany". A Christian who imitates the Saviour's kenosis (Phil 2:5-7) is heading towards resurrection. His death is the "dying of a grain of wheat" (cf. Jn 12:24), out of which grows a beautiful tree (cf. Mt 13:32; Mk 4:32), a "narrow gate" (Mt 7:13; Lk

" Jan M. Kozłowski Ph.D. - Assistant Professor in the Institute of Classical Studies at the Department of Polish Studies of the University of Warsaw; e-mail: jan.kozlowski@uw.edu.pl.

${ }^{1}$ E.g. Fronto of Cirta (II c.), in his speech against Christians (fragments of which had been preserved by Minucius Felix), says about Christians that: "They despise present torments, although they fear those which are uncertain and future; and while they fear to die after dea th, they do not fear to die (mori non timent) for the present" (Minucius Felix, Octavius 8, 5, ed. B. Kytzler, München 1965, 68, transl. R.E. Wallis, ANF 4, Buffalo 1885, 177). Galen (II c.), in a passage preserved only by an Arabic translator, wrote about Christians: "their contempt of death is patent to us every day" (S. Benko, Pagan Rome and the Early Christianity, Bloomington 1984, 41); also the testimony of the Christian convert Justin (II c.) is valuable: "Indeed, when I myself revelled in the teachings of Plato, and heard the Christians misrepresented and watched them stand fearless in the face of death and of everything that was considered dreadful, I realized the impossibility of their living in sinful pleasure. For, what sensual or self-indulgent person, who approves of the eating of human flesh, would welcome death that he might be despoiled of his pleasures [...]?" (Justinus, Apologia II 12, 1-2, ed. C. Munier, SCh 507, Paris 2006, 356, transl. T.B. Falls: The Fathers of the Church: A New Translation (Patristic Series), vol. 6, Washington D.C. 2008, 132). See Marcus Aurelius, Meditationes 11, 3 . 
$13: 24)^{2}$, through which he passes into the "broad, great light" 3 . Being counted among the martyrs is a movement "unto [the] resurrection of eternal life (cis

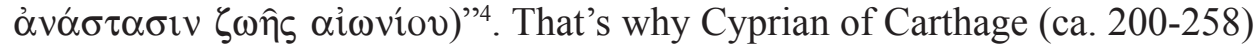
writes: "That is not an ending (exitus), but a transit (transitus), and, this journey of time being traversed, a passage (transgressus) to eternity"5. It is not surprising therefore that in ancient Christian literature suffering and death for faith were expressed in positive categories.

The witness of Christ is at the moment of his death in statu nascendi. Ignatius of Antioch, in the second century, writes about his approaching mar-

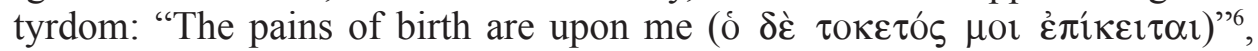
while the author of the Martyrium Polycarpi (II-III c.) calls the anniversary of

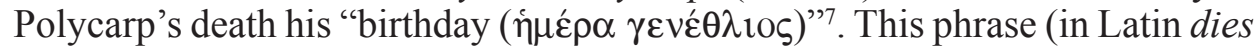
natalis) later became a technical term for the calendar anniversary of a martyr's death. For Ignatius, his martyrdom is even an indispensable condition of complete anthropogony, since he turns in his letter to the Christians of Rome with the words:

"Do not prevent me from living, do not want my death [...] Let me receive

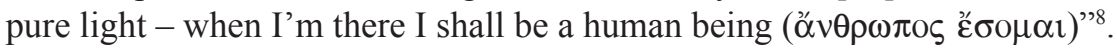

More! Already in this world Christians experience the reality of salvation. Near the end of the first century Hymenaeus and Philetus "claim that res-

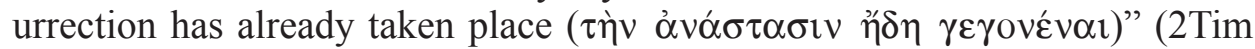
2:18). The author of the First Epistle of John at the turn of the first and second centuries writes: "We have passed from death to life $(\mu \varepsilon \tau \alpha \beta \varepsilon \beta \eta \dot{\eta} \kappa \alpha \mu \varepsilon v$

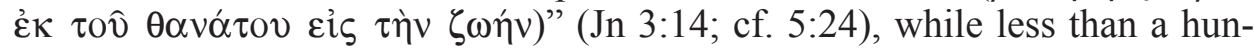
dred years later Minucius Felix puts into Octavius' mouth words: "We both rise (resurgimus) again in blessedness, and are already living (iam vivimus)

${ }^{2}$ The Greek text of the New Testament used throughout this article comes from Novum Testamentum Graece et Latine, ed. E. Nestle - E. Nestle - B. Aland - K. Aland et alii, Stuttgart 200127, in the translation of New Revised Standard Version, New York 1989.

${ }^{3}$ Martyrium Pionii 22, 1, ed. and transl. H. Musurillo, in: The Acts of the Christian Martyrs, Oxford 1972, 164-165.

${ }^{4}$ Martyrium Polycarpi 14, 2, ed. B. Dehandschutter, Polycarpiana. Studies on Martyrdom and Persecution in Early Christianity. Collected Essays, ed. J. Leemans, Bibliotheca Ephemeridum Theologicarum Lovaniensium 205, Leuven 2007, 19, transl. P. Hartog: Polycarp's Epistle to the Philippians and the Martyrdom of Polycarp: Introduction, Text, and Commentary, Oxford 2013, 259.

${ }^{5}$ Cyprianus, Liber de mortalitate 22, ed. M. Simonetti, CCL 3a, Turnhout 1976, 28-29, transl. A.C. Coxe, ANF 5, Grand Rapids 1981, 474.

${ }^{6}$ Ignatius Antiochenus, Ad Romanos 6, 1, ed. P.T. Camelot, SCh 10, Paris 1969, 132, transl. W. Schoedel: Ignatius of Antioch: a Commentary on the Letters of Ignatius of Antioch, Philadelphia $1985,181$.

${ }^{7}$ Martyrium Polycarpi 18, 3, ed. Dehandschutter, p. 21, transl. Hartog, p. 265.

${ }^{8}$ Ignatius Antiochenus, Ad Romanos 6, 2, SCh 10, 134, transl. Schoedel, p. 181. 


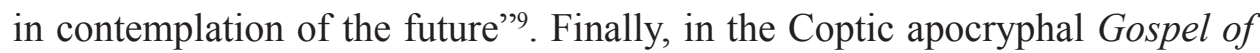
Thomas (I-II c.) we read:

"His disciples said to him: «When will the resurrection of the dead take place, and when will the new world come?» He said to them: «That resurrection which you are awaiting has already come, but you do not recognize it»" $"$

The martyr's death reveals to the world that salvation is just being realized here on this earth, according to the words of Paul the apostle:

"[...] always carrying in the body the death of Jesus, so that the life of Jesus may also be made visible ( $\varphi \alpha v \varepsilon \rho \omega \theta \hat{\eta})$ in our bodies. For while we live, we are always being given up to death for Jesus' sake, so that the life of Jesus may be made visible ( $\propto \alpha \nu \varepsilon \omega \theta \hat{)})$ in our mortal flesh" (2Cor 4:10-11).

And so, in the Acts of the Apostles we read of Stephen, ready for a martyr's death:

"All who sat in the council looked intently at him, and they saw that his face

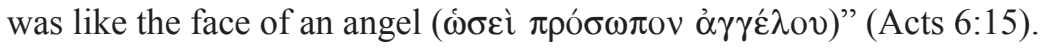

In the Martyrium Polycarpi we read about tortured martyrs, that they "were no

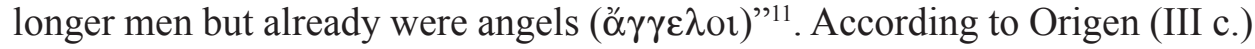

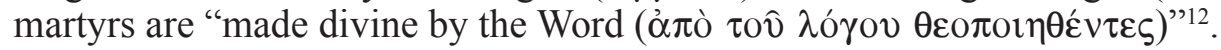

If martyrdom is a passage to everlasting life and, at the same time, a paradoxical (because, for the logic of "this world", diametrically reversed) revelation of the reality of salvation, then the instrument of torment itself, through which the martyr attains salvation, should likewise be an active "soteriophanic" element, analogously to the crown of thorns put on the head of Jesus ${ }^{13}$, or like the $\operatorname{cross}^{14}$. It is not surprising therefore that in the early Christian litera-

${ }^{9}$ Minucius Felix, Octavius 38, 4, ed. Kytzler, p. 204, ANF 4, 197.

${ }^{10}$ Evangelium Thomae Copticum 51, ed. and transl. H.G. Bethge, in: Synopsis quattuor Evangliorum: Locis parallelis evangeliorum apocryphorum et Patrum adhibitis, ed. K. Aland, Stuttgart $1996^{15}, 532$.

${ }^{11}$ Martyrium Polycarpi 2, 3, ed. Dehandschutter, p. 8, transl. Hartog, p. 243.

${ }^{12}$ Origenes, Exhortatio ad martyrium 25, ed. P. Koetschau, GCS 2 (OW 1), Leipzig 1899, 22 , own translation.

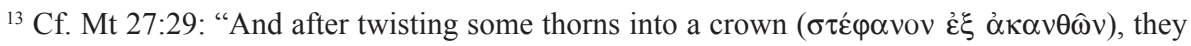
put it on his head. They put a reed in his right hand and knelt before him and mocked him, saying,

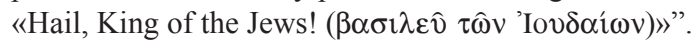

${ }^{14}$ The cross, as the symbol of the greatest humiliation (Phil 2:8; Heb 12:2), is at the same time the sign of Jesus' ontic "elevation": "«And I, when I am lifted up ( $\dot{\varepsilon} \dot{\alpha} v \dot{v} \psi \omega \theta \hat{\omega})$ from the earth, will

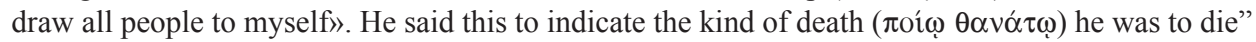
(Jn 12:32-33; cf. Jn 3:14-15); Christ's "elevation" on the cross is His direct theophany: "When you

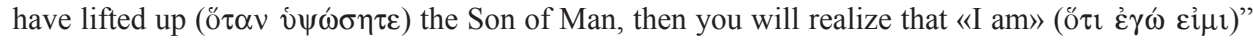
(Jn 8:28). The background for these symbolic dimensions of the cross is the "objective" ontic elevation of the formerly humiliated Son of God, as it is expressed in the Paul's Epistle to Philippians in 
ture of martyrdom the instruments of torment are often presented as an integral part of the manifestation of salvation through the martyr.

Though this paradox is an apparent and distinct topos, one observes, in studies devoted to the literature and theology of martyrdom of the first centuries A.D., either a complete neglect of the issue of a positive function of the instruments of torment ${ }^{15}$, or else a superficial mention of it $^{16}$.

The aim of the current paper is to fill this gap: I will analyze representative passages from second and third century Christian literature ${ }^{17}$, in which, in the elements of the torment inflicted upon martyrs, the Christian authors see:

1. the reality of "passage" (transitus) to eternal life;

2. paradoxical manifestation (by external analogy) of the images of the reality of salvation as found in Biblical texts, in a way similar to the "elevation" of Jesus on the cross (see note 14);

3 . images diametrically opposed to those of the reality of salvation (e.g. darkness, stench), which paradoxically become an inspiration to

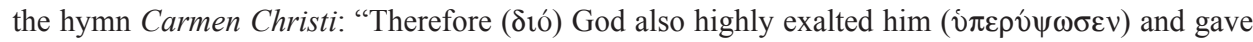
him the name that is above every name" (Phil 2,9).

${ }^{15}$ Cf. P. Hartog, Polycarp's Epistle to the Philippians and the Martyrdom of Polycarp: Introduction, Text, and Commentary, Oxford 2013; C.R. Moss, Ancient Christian Martyrdom: Diverse Practices, Theologies, and Traditions, New Haven 2012; C.R. Moss, The Other Christs: Imitating Jesus in Ancient Christian Ideologies of Martyrdom, New York 2010; M. Wysocki, Eschatologia okresu prześladowań na podstawie pism Tertuliana i Cypriana, Lublin 2010; M.-F. Baslez, Les persécutions dans l'Antiquité. Victimes, héros, martyrs, Paris 2007; Dehandschutter, Polycarpiana; F. Avemarie - J.-W. van Henten, Martyrdom and Noble Death. Selected Texts from Graeco-Roman, Jewish and Christian Antiquity, London - New York 2002; D. Karłowicz, Arcyparadoks śmierci. Męczeństwo jako kategoria filozoficzna - pytanie o dowodowa wartość męczeństwa, Warszawa 2007; Th. Baumeister, Genèse et évolution de la théologie du martyre dans l'Église ancienne, Bern 1991; Atti e Passioni dei Martiri, Scrittori Greci e Latini, ed. A.A.R. Bastiaensen - A. Hilhorst G.A.A. Kortekaas - A.P. Orbán - M.M. van Assendelft, Milano 1987; The Acts of the Chrisitan Martyrs, ed. H. Musurillo, Oxford 1972; H. Delehaye, Les passions des martyrs et les genres littéraires, Subsidia Hagiographica 13, Bruxelles $1966^{2}$.

${ }^{16}$ Cf. T.J. Heffernan - J.E. Shelton, Paradisus in carcere: The Vocabulary of Imprisonment and the Theology of Martyrdom in the "Passio Sanctarum Perpetuae et Felicitatis", JECS 14 (2006) 217-223; G. Buschmann, Das Martyrium des Polykarp übersetzt und erklärt, Kommentar zu den Apostolischen Vätern 6, Göttingen 1998, 301; V. Saxer, Bible et hagiographie. Textes et thèmes bibliques dans les Actes des martyrs authentiques des premiers siècles, Bern 1986, 238; W. Schoedel, Ignatius of Antioch: a Commentary on the Letters of Ignatius of Antioch, Philadelphia 1985, 72 and 176; C.-M. Edsman, Ignis Divinus. Le feu comme moyen de rajeunissement et d 'immortalité: Contes légendes mythes et rites, Lund 1949, 170. See J.M. Kozłowski, Płonat ogniem, a nie spalat się. Analiza i interpretacja Martyrium Polycarpi 15, 2, Warszawa 2014, 105-108.

${ }^{17} \mathrm{Cf}$. Ignatius Antiochenus, Epistula ad Ephesios 11, 2; idem, Epistula ad Romanos 4, 1; Polycarpus, Epistula ad Philippenses 1, 1; Martyrium Lugdunensium 1, 35; Martyrium Polycarpi 5, 2; 15, 2; Tertullianus, Apologeticum 50, 3; idem, Ad martyras 2, 4; Passio Perpetuae et Felicitatis 21, 2-3; Martyrium Pionii 7, 4; 20, 5-6; Cyprianus Carthaginiensis, Epistula 76, 2-4. 
remind one of the participation of martyrs in the reality of salvation, their ontic "elevation" (respectively: light, beautiful fragrance).

Each of the analyzed passages can be matched to one of the above-mentioned categories of the paradoxical reevaluation of the instrument of torment. I will divide this material into the following chapters: 1) prison (+ mines); 2) fighting with animals in the amphitheater (venationes); 3 ) burning at the stake.

1. Prison. Before they were executed, Christians were often imprisoned. Christian writers discerned in those elements that formed the reality of the prison either an "objective", paradoxical manifestation of the reality of salvation or - on the basis of diametrical opposition - an image of the participation of the martyr in the reality of salvation.

Tertullian (II-III c.), in a short treatise addressed to Christians suffering from the hard conditions of prison, juxtaposes the tedious reality of the carcer with their sanctity:

"It is full of darkness (tenebrae), but you yourselves are light (lumen); it has bonds (vincula), but God has made you free (soluti). Unpleasant exhalations are there (triste illic exspirat), but you are an odor of sweetness (odor suavitatis)" ${ }^{\prime \prime 18}$.

Impenetrable darkness, bonds and prison stench unexpectedly become for Tertullian an impulse to perceive in the presence of the martyrs some "objective" elements of the reality of salvation. The darkness reveals the truth that Christians are "the light of the world (lux mundi)" (Mt 5:14). It reminds us that: "the light (lux) shines in the darkness, and the darkness (tenebrae) did not overcome it" (Jn 1:5). Bonds, with which they are tied, remind us that Christians are in fact free, as it is written in the New Testament:

"For whoever was called in the Lord as a slave is a freed person belonging to the Lord (libertus est Domini)" (1Cor 7:22);

"For the law of the Spirit of life in Christ Jesus has set you free (liberaverit) from the law of sin and of death" (Rom 8:2);

"So if the Son makes you free, you will be free (liberi) indeed" (Jn 8:36).

Finally, the stench which fills the carcer reminds us that Christians are the "odor of sweetness (odor suavitatis)" "19. In the Old Testament, very often,

${ }^{18}$ Tertullianus, Ad martyras 2, 4, ed. E. Dekkers, CCL 1, Turnhout 1954, 4, transl. S. Thelwall, ANF 3, Grand Rapids 1980, 693-694.

${ }^{19} \mathrm{Cf}$. B. Kötting, Wohlgeruch der Heiligkeit, in: Jenseitsvorstellungen in der Antike und Christentum. Gedenkschrift für A. Stuiber, JbAC Ergänzungsband 9, ed. Th. Klauser - E. Dassmann K. Thraede, Münster 1982, 168: "Diese Formulierung scheint Tertullian so selbstverständlich aus der Feder zu fließen, dass es sich offentsichtlich um ein Bild handelt, das zu seiner Zeit in der christlichen Predigt und Katechese gebräuchlich war". 
where there is talk of a burnt offering (holocaust), this expression appears

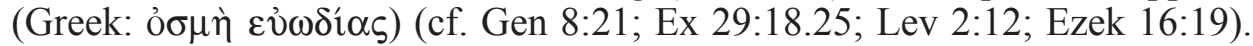
The expression appears also in the early Christian literature with metaphorical meaning, when it refers to the sacrifice of Jesus, who "gave himself up for

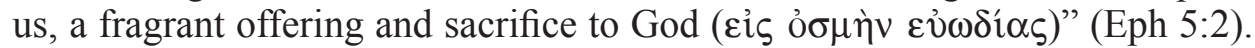
We can see then, how elements of the reality of imprisonment inspire Tertullian to find in the Holy Scripture diametrically opposite, but at the same time negatively analogous images of the reality of salvation, which "objectively" describe the condition of the Christians awaiting execution.

In one of the Epistles of Cyprian, we find a similar passage, comprising a series of images that describe the situation of imprisoned Christians, with the difference that here we are dealing with those condemned to the mines. The bishop of Carthage writes:

"But what wonder if, as «golden and silver vessels» (vasa aurea et argentea), you have been committed to the mine (metallum) that is the home of gold and silver (auri et argenti domicilium), except that now the nature of the mines is changed, and the places, which previously had been accustomed to yield gold and silver, have begun to receive them? Moreover, they have put fetters on your feet, and have bound your blessed limbs, and the temples of God (Dei templa) with disgraceful chains [...] To men who are dedicated to God (dictatis Deo), and attesting their faith with religious courage, such things are ornaments, not chains (ornamenta sunt ista, non vincula); [...] The body is not cherished in the mines with couch and cushions, but it is cherished with the refreshment and solace of Christ (refrigerium et solacium Christi). The frame wearied with labors lies prostrate on the ground, but it is no penalty to lie down with Christ (cum Christo iacere). [...] There the bread is scarce; but man lives not by bread alone, but by the word of God (non in solo pane vivit homo, sed in sermone Dei). Shivering, you want clothing; but he who puts on Christ (qui Christum induit) is both abundantly clothed and adorned. The hair of your half-shorn head seems repulsive; but since Christ is the head of the man (cum sit caput viri Christus), anything whatever must needs become that head which is illustrious on account of Christ's name"20.

Tertullian opens the series of paradoxical images by recalling the fact that Christians are located in a place where precious metals are mined (metallum). He takes the opportunity to remind us that Christians are called to be, according to the Second Epistle to Timothy, "utensils of gold and silver (vasa aurea et argentea)" (2Tim 2:20; cf. 2:21). It is possible that Cyprian is also referring to those places in Holy Scripture where, when there is mention of the treasury pillaged from the Temple of Jerusalem, there often appears the expression

${ }^{20}$ Cyprianus Carthaginiensis, Epistula 76, 2, ed. G.F. Diercks, CCL 3c, Turnhout 1996, 608610, transl. A.C. Coxe, ANF 5, 403. 
vasa aurea et argentea (for example Dan 5:3; 1Mac 6:12; Ezra 1:11; 5:14; 6:5). Further on Cyprian writes that the bonds with which the Christians are tied are in reality "ornaments" (ornamenta). Since the bonds are ornaments for those who are dedicated to God (dictatis Deo), the context suggests a continuation of the metaphor of a Christian as the Temple of God (Dei templa). One cannot exclude the possibility that Cyprian wishes to remind the addressees of his letter of the ornaments which adorned the Temple in Jerusalem: "[...] some were speaking about the temple (templum), how it was adorned (ornatum) with beautiful stones and gifts dedicated to God" (Lk 21:5). A reference to the Book of Revelation is also possible: "And I saw the holy city, the new Jerusalem, coming down out of heaven from God, prepared as a bride adorned for her husband (ornatam viro suo)" (Rev 21:2). In the image that follows, the discomfort caused by the lack of bedding becomes an impulse to remind us that for Christians, the only source of real refreshment (refrigerium) and consolation (consolatio) is the Christ himself: "We went through fire and through water; yet you have brought us out to a spacious place (refrigerium)" (Ps 65:12), and "For just as the sufferings of Christ are abundant for us, so also our consolation (consolatio) is abundant through Christ" (2Cor 1:5). Scarcity of food becomes a pretext to remind us of the truth that "one does not live by bread alone, but by every word that comes from the mouth of the Lord" (Deut 8:3; Mt 4:4). In the fact that Christians were made to lay on the ground Cyprian sees a parallel to the reclining (erat recumbens) of Jesus' beloved disciple on his Savior's chest during the Last Supper (Jn 13:23). Lack of clothing and suffering from cold remind us that the apostle Paul calls Christians to "put on (induamini!) Jesus Christ" (Rom 13:14). Finally the half-shorn head becomes an inspiration to remind readers that the true head of a Christian is Christ himself, according to what Paul writes in his letter to the Corinthians: "Christ is the head of man (viri caput Christus est)" (1Cor 11:3). We can see, therefore, that the elements of the reality of imprisonment, for Tertullian as for Cyprian, constitute either a paradoxical manifestation or a negative reflection of the reality of salvation as it is described in Holy Scripture.

Among the items connected with loss of freedom, it is especially in bonds ( $\tau \grave{\alpha} \delta \varepsilon \sigma \mu \alpha \dot{\alpha}, v i n c u l a$ ), which were a clear, external sign of captivity ${ }^{21}$, that

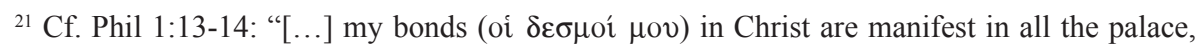
and in all other places. And many of the brethren in the Lord, waxing confident by my bonds ( $\tau$ oî $\delta \varepsilon \sigma \mu \circ \hat{i} \varsigma \mu \mathrm{ov})$, are much more bold to speak the word without fear". See Martyrium Pionii 2, 3-4:

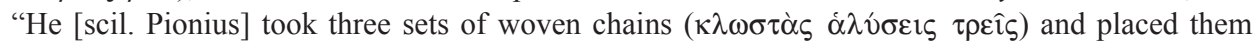
around his own neck and the necks of Sabina and Asclepiades, and thus entertained them in his house. He did this with a view to those who were to arrest him, lest any be given to suspect that they were being induced to eat forbidden foods as the others were, but rather that all should know that they were determined to be led off to prison forthwith", ed. and transl. Musurillo, p. 136-137. Ignatius, transported to Rome to die in the arena, unceasingly emphasizes in his epistles, that he wears bonds. Cf. Ignatius Antiochenus, Epistula ad Ephesios 1, 2; 3, 1; 11, 2; 21, 2; idem, Epistula 
Christian writers saw a paradoxical manifestation of the reality of salvation. Already in the fragments from African writers quoted above, the bonds (vincula) were called ornamenta and reminded us that the Christian had been liberated by God (Deo soluti). In the earlier Greek literature of martyrdom, we sometimes find a metaphorical treatment of bonds. Ignatius of Antioch defines the bonds ( $\tau \grave{\alpha} \delta \varepsilon \sigma \mu \alpha$ ) with which he is tied as "spiritual pearls ( $\alpha i \pi v \varepsilon v \mu \alpha \tau \imath \kappa \alpha i ̀ ~$ $\left.\mu \alpha \rho \gamma \alpha \rho^{\prime} \tau \alpha \mathrm{l}\right)$ "'22, in which he longs to be resurrected. Perhaps this is intended an echo of the Gospel of Matthew, where the Kingdom of God is compared

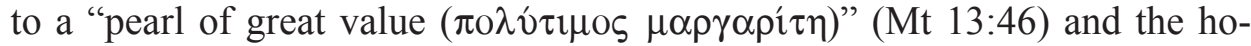
liness of Christians (confronted with the impiety of others) is compared to pearls ( $\mu \alpha \rho \gamma \alpha \rho i \tau \alpha \imath i \mu \hat{\omega} v)$ (cf. Mt 7:6). The motif of bonds as a paradoxical ornament also appears in Polycarp's Epistle to Philippians, where the bonds ( $\tau \grave{\alpha} \delta \varepsilon \sigma \mu \alpha$ ) with which Ignatius and his companions were tied are called "the diadems $(\delta 1 \alpha \delta \eta \mu \alpha \tau \alpha)$ of them that have been truly elected by God and our Lord"23. Polycarp here refers unambiguously to Ignatius' epistles, but clearly the word $\delta 1 \alpha \delta \eta \mu \alpha \tau \alpha$ evokes also a passage from the Book of Wisdom:

"But the upright live forever, their recompense is with the Lord, and the Most High takes care of them. So they will receive the glorious crown and the diadem

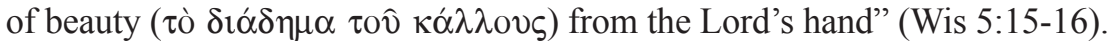

In the Martyrium Lugdunensium, we read that the bonds ( $\tau \dot{\alpha} \delta \varepsilon \sigma \mu \alpha$ ) of the martyrs:

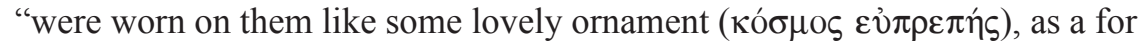

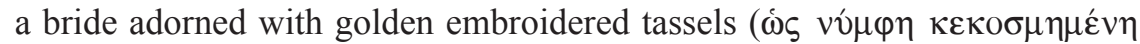

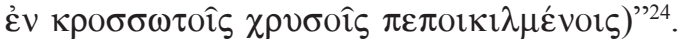

The author of the martyrdom refers here to the Book of Psalms, where there is mention of a royal daughter who is "robed in golden fringed garments

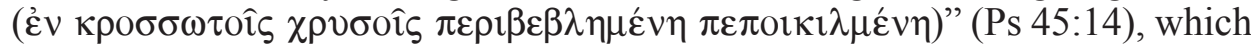
passage was interpreted by Christians eschatologically. Clement of Alexandria in his Paedagogus writes that the psalmist had in mind:

"the immortal adornment, woven of faith, of those that have found mercy,

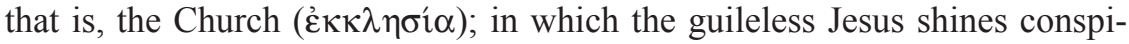

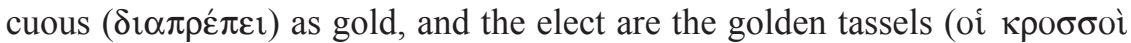
oi $\chi \rho \vee \sigma o \hat{\imath}) " 25$.

ad Magnesios 1, 2; 12, 1; idem, Epistula ad Trallianos 1, 1; 5, 2; 10, 1; 12, 2; idem, Epistula ad Romanos 1, 1; 4, 3; idem, Epistula ad Filadelphios 5, 1; 7, 1; idem, Epistula ad Smyrnaeos 4, 2; 10 , 2; 11, 1; idem, Epistula ad Polycarpum 2, 3).

${ }^{22}$ Ignatius Antiochenus, Epistula ad Ephesios 11, 2, ed. P.T. Camelot, SCh 10, 80, own translation.

${ }^{23}$ Polycarpus, Epistula ad Philippenses 1, 1, ed. P.-Th. Camelot, SCh 10, Paris 1969, 176, transl. P.N. Harrison: Polycarp's Two Epistles to the Philippians, Cambridge 1936, 321, 328.

${ }^{24}$ Martyrium Lugdunensium 1, 35, ed. and transl. H. Musurillo, in: The Acts of the Christian Martyrs, p. 72-73.

${ }^{25}$ Clemens Alexandrinus, Paedagogus II 110, 2, ed. M. Marcovich: Clementis Alexandrini 
2. Venationes. Games reminded the conquered populace of the Roman rule and constituted an important element of romanization, very much like the gymnasium acted as a symbol of hellenization ${ }^{26}$. Wherever the Romans spread their imperium, amphitheaters were constructed. Christians often ended their lives in the arenas of amphitheaters used for venationes, wild-animal spectacles. "Paradoxically, venationes also contributed to the spread of Christianity. For many a pagan it was the first opportunity to reflect on the source of spiritual strength of those men and women who went to death of their own will, overcoming the fear of it" ${ }^{27}$. In the literature of martyrdom we meet at least two images, where the reality of venationes was used to illustrate the dynamics of the "passage" (transitus) from this world to the reality of salvation.

In Passio Perpetuae (III c.), at the end of venationes, Saturus is thrown into the arena to fight a leopard. After a single bite from the animal (de uno morsu), he is abundantly drenched with blood (tanto perfusus est sanguine). Seeing this the pagan spectators roar: Salvum lotum! Salvum lotum! ("Well washed! Well washed!"' ${ }^{28}$. The roar is deeply rooted in the everyday life of the Roman province. At Brescia in the mosaic floor of a nymphaeum two inscriptions were found: Bene lava! and Salvum lotum! ${ }^{29}$. According to Antoon Bastiaensen, this was an elliptic formula for: Salvum lotum te esse optamus ("We wish you be well washed") ${ }^{30}$. For the author of Passio Perpetuae et Felicitatis, this roar of the pagan spectators is a testimony of Saturus' "second baptism" (secundi baptismatis testimonium). From very early on Christians associated martyrdom with baptism. After all, the martyr is one for whom the certainty of attaining salvation is without question, since he has obliterated all his sins by his suffering and death. Already in the Gospel of Mark, Jesus turns to the sons of Zebedee, who want to be seated at his right and left hand, saying:

"You do not know what you are asking. Are you able to drink the cup that I drink, or be baptized with the baptism ( $\tau$ ò $\beta$ ó $\pi \tau \imath \sigma \mu \alpha$ ) that I am baptized with?" (Mt 10:38).

Paedagogus, Supplements to VigCh 61, Leiden - Boston 2002, 135, transl. A.C. Coxe, ANF 2, Grand Rapids 1983, 266.

${ }^{26}$ Cf. L.L. Thompson, The Martyrdom of Polycarp: Death in the Roman Games, "The Journal of Religion" 82 (2002) 31; E. Gunderson, The Ideology of the Arena, "Classical Antiquity" 15 (1996) 146.

${ }^{27}$ E. Wipszycka, Prześladowania w Państwie Rzymskim, in: Męczennicy, ed. E. Wipszycka M. Starowieyski, OŻ 9, Kraków 1991, 77-78, own translation.

${ }^{28}$ Passio Perpetuae et Felicitatis 21, 2, ed. and transl. H. Musurillo, in: The Acts of the Christian Martyrs, p. 128-129.

${ }^{29}$ H. Dessau, Inscriptiones Latinae selectae, vol. 2/1, Berlin 1902, no 5725.

${ }^{30}$ A.A.R. Bastiaensen, Commento alla Passio Perpetuae et Felicitatis, in: Atti e Passioni dei Martiri, p. 449. 
In the writings of Tertullian, who shared the same African Sitz im Leben with the author of Passio Perpetuae et Felicitatis, we read that martyrdom is "another baptism (aliud baptisma)" "31 as well as the following passage: "We have indeed, likewise, a second font (lavacrum) - itself withal one with the former - of blood (sanguinis scilicet)" ${ }^{\prime 32}$. The image in Passio Perpetuae is of course deeply ironic, since, in the reality of faith, the derisory wish of the pagan audience is being realized. The author of the passion writes later: "For well washed (salvus) indeed was one who had been bathed in this manner (laverat)" ${ }^{\prime 33}$. Here too the material reality of "this world" reveals the dynamics of the "passage" (transitus) towards the reality of salvation.

Perhaps the best known passage in early Christian literature, where the instrument of torment is pictured as a paradoxical instrument of the transitus, is to be found in the epistles of Ignatius of Antioch. The Syrian bishop, who expects his death to come during ventationes, asks Roman Christians not to try to rescue him:

"Let me be the food of wild beasts through whom ( $\left.\delta \imath^{\prime} \hat{\omega} v\right)$ it is possible to

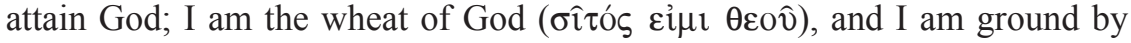

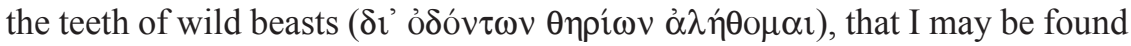

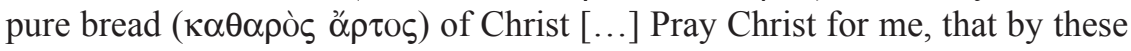

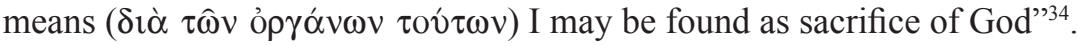

Which wild animal is he referring to? The leopard, perhaps, since a moment later Ignatius metaphorically calls the soldiers escorting him "leopards" $(\lambda \varepsilon \operatorname{có} \alpha \rho \delta \mathrm{ol})^{35}$.

Ignatius wants to imitate his Master in his death. He wants to transform himself into Him. The only form of the body of the risen Christ accessible to the senses of Christian believers is the bread of the Eucharist, to which Ignatius devotes much attention in his letters ${ }^{36}$. Imitation of Christ attains its telos in the conformation to His body. Bread (like wine, which is born out of the destruction of the fruit of the vine) is formed by the destruction of the grain. A parallel therefore is drawn between the formation of bread and a martyr's death, analogous to that between production of the wine and the shedding of blood ${ }^{37}$. Moreover, at least two images from the New Testament reinforce this identification:

${ }^{31}$ Tertullianus, De pudicitia 22, 9, ed. E. Dekkers, CCL 2, Turnhout 1954, 1329, own translation.

${ }^{32}$ Idem, De baptismo 16, 1, ed. J.G.Ph. Borleffs, CCL 1, 290, transl. S. Thelwall, ANF 3, 677.

${ }_{33}^{33}$ Passio Perpetuae et Felicitatis 21, 3, ed. Musurillo, p. 130-131.

${ }^{34}$ Ignatius Antiochenus, Epistula ad Romanos 4, 1-2, SCh 10, 130, transl. Schoedel, p. 175.

${ }^{35}$ Ibidem 5, 1, SCh 10, 130, transl. Schoedel, p. 178.

${ }^{36}$ Cf. Ignatius Antiochenus, Epistula ad Ephesios 1, 5. 20; idem, Epistula ad Trallianos 8, 1; idem, Epistula ad Romanos 7, 2; idem, Epistula ad Smyrnaeos 12, 2.

${ }^{37}$ In Achilles Tatius' (II c. A.D.), The Adventures of Leucippe and Clitophon the herdsman Icarius asks a question to Dionysus who gives him to drink for the first time a cup of wine: "Where 
"Fool! What you sow (ô $\sigma \pi \varepsilon i ́ \rho \varepsilon ı$ ) does not come to life unless it dies

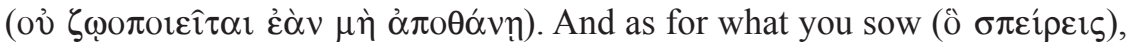

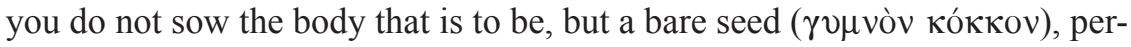
haps of wheat ( $\sigma$ í $\tau$ ov) or of some other grain" (1Cor 15:36-37),

as well as:

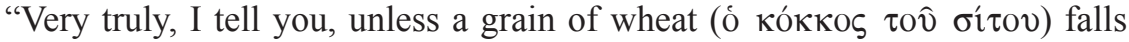
into the earth and dies ( $\alpha \pi \circ \theta \alpha \dot{\alpha} v)$, it remains just a single grain; but if it dies

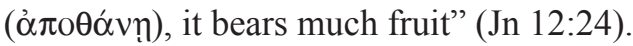

It is likely that Ignatius, directly or indirectly, is alluding to these two passages. In the teeth of animals Ignatius sees a millstone that will transform the grain of his body into flour, out of which the "pure bread of Christ" (see above) will be formed. Animals' teeth are necessary "means (ó $\rho \gamma \alpha \nu \alpha)$ )"38 to ensure that the grain, which is Ignatius himself, will be transformed into eschatological bread.

3. Burning at the stake. The penalty of burning at the stake was very often imposed upon Christians ${ }^{39}$. The condemned man was undressed and nailed down or tied to the stake, which was surrounded with brushwood and kindling and then set on fire. In the Martyrium Polycarpi, pagans mob, since they cannot use Polycarp for venationes, decide "with one accord (o $\mu \circ \theta v \mu \alpha \delta$ óv)" highlighted by the author of martyrdom, to burn him alive. In the Martyrium Pionii, Pionius turns to the pagans saying: "Would that I were able to persuade you to become Christians", to which they respond: "You have not such power that we should be burnt alive (iv $\alpha \hat{\omega} \nu \tau \varepsilon \varsigma \kappa \alpha \hat{\omega} \mu \varepsilon v)$ ""41. Being Christian is, according to the pagans, equal to being "burnt alive". Under Decius, during the bloody persecution of Christians in Alexandria, where wood was a rare material, persecutors threatened that anyone who did not deny the Christian faith

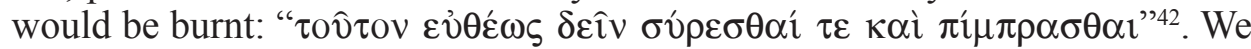
see that it must therefore have been a punishment used against Christians with

did you get this purple water, my friend. Wherever did you find blood ( $\alpha \hat{i} \mu \alpha)$ so sweet?", to which

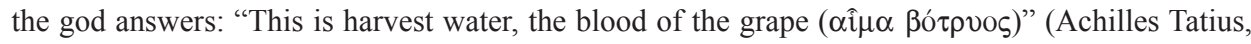
Leucippe et Clitophon II 2, 4-5, transl. S. Gaselee: Achilles Tatius, The Adventures of Leucippe and Clitophon, ed. E. Capps - W.H.D. Rouse, London 1917, 57-60). Cf. K. Spanoudakis, Icarius Jesus Christ? Dionysiac Passion and Biblical Narrative in Nonnus' Icarius Episode (Dion. 47, 1-264), "Wienner Studien" 120 (2007) 48-49.

${ }^{38}$ Ignatius Antiochenus, Epistula ad Romanos 4, 2, SCh 10, 130, transl. Schoedel, p. 175.

${ }^{39}$ Cf. P. Keresztes, From the Great Persecution To the Peace of Galerius, VigCh 37 (1983) 381; A.P. Orbán, Comento al "Martyrium Polycarpi", in: Atti e Passioni dei Martiri, p. 378; Wipszycka, Prześladowania w Państwie Rzymskim, p. 72; Buschmann, Das Martyrium des Polykarp, p. 295.

${ }^{40}$ Martyrium Polycarpi 12, 3, ed. Dehandschutter, p. 16, transl. Hartog, p. 257.

${ }^{41}$ Martyrium Pionii 7, 3-4, ed. and transl. Musurillo, p. 144-145.

${ }^{42}$ Eusebius Caesarensis, HE VI 41, 8, ed. T.E. Page et allii: Eusebius, The Ecclesiastical History, vol. 2, Cambridge 1964, 102. Cf. ibidem VI 41, 7. 14. 19-20. 
particular frequency. In this case, the reality of the torment was furthermore an opportunity to see a picture of the actual "elevation" of the martyr, as in the process of the "dying of a grain of wheat" and as in the passing through a "narrow gate".

In his Apologeticum, Tertullian turns to the pagans, saying:

"Call us, if you like, Sarmenticii and Semaxii, because bound to a half-axle stake (ad stipitem dimidii axis revincti), we are burnt in a circular heap of faggots

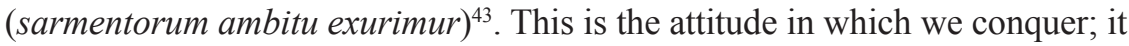
is our victory-robe (habitus victoriae nostrae); it is for us a sort of triumphal chariot (tali curru triumphamus)" ${ }^{\prime 4}$.

Beyond showing us that the penalty of burning at the stake was often used against Christians, the passage from Tertullian shows offers us a paradoxical actualization of the reality of Christian salvation: the pyre is like a chariot (currus), on which the victorious emperor rode during moments of triumph (triumphus, $\theta$ pi $\alpha \mu \beta о \varsigma$ ), and the brushwood is compared to the garments in which he was clothed (habitus victoriae; palmata vestis). As for the "triumph" itself (triumphus, $\theta$ pí $\mu \beta \beta_{\text {) }}$ ), in the Greek and Roman languages this word was often used as a metaphorical synonym of "victory" 45 .

What is important is that the image of triumph, in the technical sense of the word, appears in the New Testament to depict an eschatological victory. In the Epistle to the Colossians, Pseudo-Paul writes:

"[...] erasing the record that stood against us with its legal demands. He set this aside, nailing it to the cross. He disarmed the rulers and authorities and

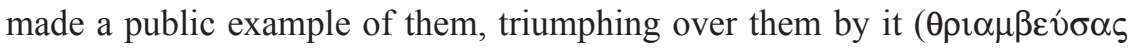

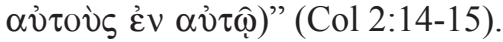

Tertullian refers then to this well-known image from Holy Scripture.

The expression habitus victoriae clearly connotes the images in Revelation:

"He who overcomes will thus be clothed in white garments (qui vicerit, vestietur vestimentis albis)" (Rev 3:5);

"robed in white (amicti stolis albis), with palm branches (palmae) in their hands" (Rev 7:9);

${ }^{43}$ Cf. Martyrium Pionii 21, 5-7, ed. and transl. Musurillo, p. 164-165 "And so they raised him up on the gibbet, and then afterwards a man named Metrodorus from the Marcionite sect. [...] After

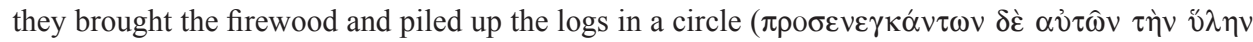

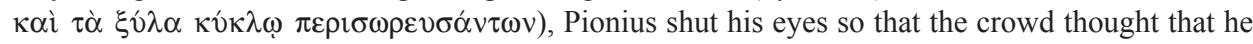
was dead".

${ }^{44}$ Tertullianus, Apologeticum 50, 3, ed. E. Dekkers, CCL 1, 169, transl. S. Thelwall, ANF 3, 54-55.

${ }^{45}$ Cf. Liddell - Scott $($ Oxford 19969), 806; P.G.W. Glare, Oxford Latin Dictionary, Oxford 1968, 1979. 
"These are they who have come out of the great ordeal; they have washed their robes (stolas suas) and made them white in the blood of the Lamb" (Rev 7:14).

We can see therefore, that the notion of habitus victoriae finds its correspondence in Christians' depictions of the reality of salvation inspired by Holy Scripture. Admittedly, the clothes of the redeemed Christians in Revelation do not coincide precisely with tunica palmata, nonetheless there is still a degree of correspondence between the images: the redeemed Christians hold in their hands palms, which in the ancient world were a universal symbol of victory ${ }^{46}$.

In Greek, the expression $\tau$ ò $\zeta \hat{\omega} \nu \tau \alpha \kappa \alpha \hat{\eta} v \alpha \imath$ was a technical term for "being burnt alive" ${ }^{47}$. If the condemned man somehow survived the execution, the "Greek ear" could interpret the participle $\zeta \hat{\omega} v$ literally, as "living" in the sense of "survival": in Onirocriticon of Artemidorus (II c. A.D.), we find the following interpretation of a dream concerning being burnt alive:

"[...] being burnt alive ( c̀ $_{\zeta} \hat{\omega} \nu \tau \alpha \kappa \alpha \tau \alpha \kappa \alpha i \varepsilon \sigma \theta \alpha \imath$ ) for the sick, because of

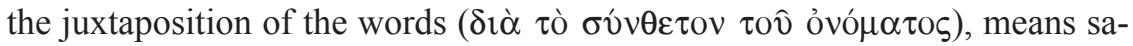
lvation $(\sigma \omega \tau \eta \rho i ́ \alpha \nu)^{\prime 48}$.

The potential paradoxicality of this expression is palpable in the Martyrium Polycarpi $^{49}$. Three days before his arrest, the Smyrnean bishop Polycarp receives a vision during a prayer in which he sees his pillow being consumed by fire, which he interprets in a prophetic manner, saying: "It is necessary to me to be burnt alive $(\delta \varepsilon \hat{\imath} \mu \varepsilon \zeta \hat{\omega} \nu \tau \alpha \kappa \alpha v \theta \hat{\eta} v \alpha \imath)$ " ${ }^{50}$. Polycarp survives the fiery execution. Since he is described as a prophetic teacher ( $\delta 1 \delta \alpha \sigma \kappa \alpha \lambda \circ \varsigma \pi \rho \circ \varphi \eta \tau \imath \kappa o ́ \varsigma)$ and we learn that "every word $(\pi \hat{\alpha} \nu \hat{\rho} \hat{\eta} \mu \alpha)$ that he uttered from his mouth was

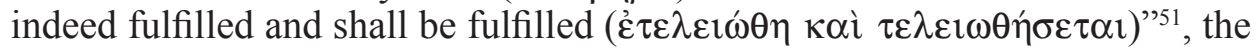
only way to interpret this discrepancy is to interpret his prophetic words literally. However it is not the case that Polycarp does not enter into reaction with

${ }^{46}$ J.P. Brown, Israel and Hellas, vol. 2: Sacred Institutions with Roman Counterparts, Beihefte zur Zeitschrift für die alttestamentliche Wissenschaft 276, Berlin 2000, 264-265.

${ }^{47}$ E.g. Herodous, Historiae 1, 86, ed. Ph.-E. Legrand: Hérodote, Histoires, Paris 1932, 87:

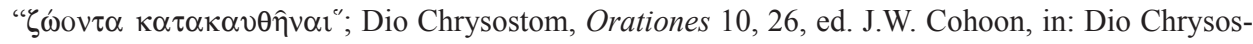

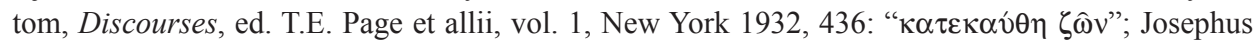
Flavius, Bellum Judaicum 7, 450, ed. H.St.J. Thackeray, in: Josephus, The Jewish War, Books IV-VII,

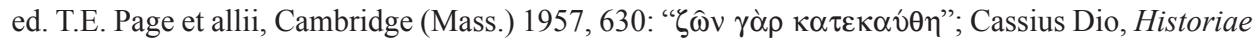
Romanae 67, 16, 3, ed. H.B. Foster, in: Dio's Roman History, ed. T.E. Page et allii, vol. 8, Cambridge

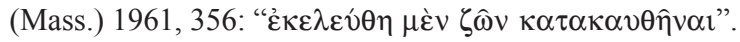

${ }^{48}$ Artemidorus Daldianus, Onirocriticon 2, 52, ed. R.A. Pack, Artemidori Daldani Onirocriticon libri V, Leipzig 1963, 183, own translation. See J.M. Kozłowski, ”And He Saw His Pillow Being Consumed by Fire" (Martyrium Polycarpi 5, 2). A Proposal of Interpretation, EThL 85 (2009) 150-151.

${ }^{49}$ Cf. Kozłowski, Płonat ogniem, a nie spalat sie, p. 73-77.

${ }^{50}$ Martyrium Polycarpi 5, 2, ed. Dehandschutter, p. 10, transl. Hartog, p. 247.

${ }^{51}$ Ibidem 16, 2, ed. Dehandschutter, p. 19, transl. Hartog, p. 263. 
the fire at all. In the description of what happens with Polycarp's body on the

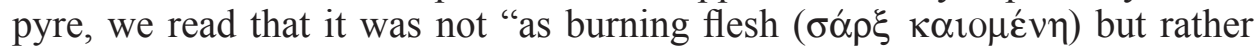

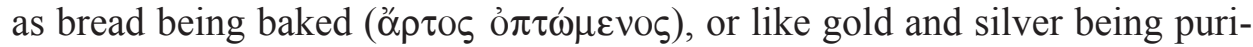

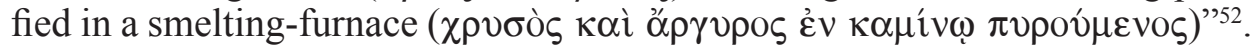
Polycarp's body, which enters into reaction with the instrument of torment, is compared to "bread" (ő $\rho \tau o \varsigma)$. Eucharistic connotations are evident ${ }^{53}$. We are dealing here with an image analogous to earlier presented in Ignatius (see above), with the difference that, instead of animals, we encounter fire. Still, in the context of the martyr's death, Martyrium Polycarpi refers to another stage of the formation of Eucharistic bread ${ }^{54}$. As for the comparison to "gold and silver being purified in a smelting-furnace", we have here a metaphor of purification and of testing by God, an image often encountered in the Old Testament. And so, for example, in the Book of Malachi God announces that he will sent a messenger to prepare the way before Him who "will purify the descendants of Levi and refine them like gold and silver" (Mal 3:3); in the Book of Zechariah God says: "And I will put this third into the fire, refine them as one refines silver, and test them as gold is tested" (Zech 13:9) ${ }^{55}$. We find a similar picture in the First Epistle to the Corinthians, where Paul, speaking of Christian missionaries who build the Church in Corinth, writes:

"Now if anyone builds on the foundation with gold, silver, precious stones,

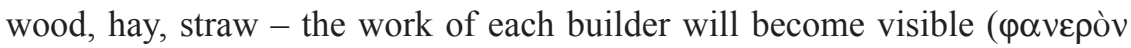

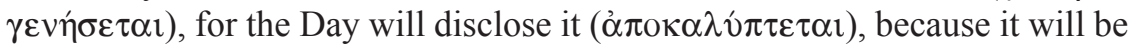

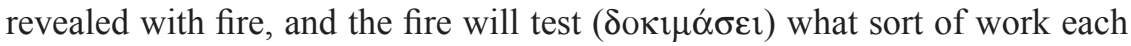
has done" (1Cor 3:12-13).

Thus we see that gold and silver melted in a furnace, and in this way purified from dirt, constituted an obvious telos of salvation for ancient Christians.

In Marytrium Pionii, there is a play on words similar to the one in the Martyrium Polycarpi. Here, too, there is an analogous yielding of paradoxical meaning

${ }^{52}$ Ibidem 15, 2, ed. Dehandschutter, p. 19, transl. Hartog, p. 261.

${ }^{53}$ Cf. Buschmann, Das Martyrium des Polykarp, p. 292.

${ }^{54}$ Cf. Martyrium Polycarpi 15, 2. See Irenaeus Lugdunensis, Adversus haereses V 28, 4, ed. A. Rousseau, SCh 153, Paris 1969, 360-362, transl. A.C. Coxe, ANF 1, Grand Rapids 1981, 557: "And therefore throughout all time, man, having been moulded at the beginning by the hands of

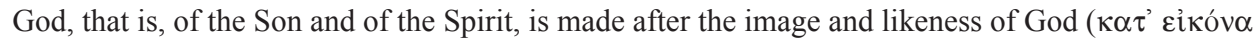

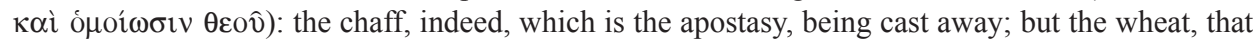
is, those who bring forth fruit to God in faith, being gathered into the barn. And for this cause tribulation ( $\dot{\eta} \theta \lambda \hat{\imath} \psi 1 \varsigma$ ) is necessary for those who are saved, that having been after a manner broken up, and rendered fine ( $\lambda \varepsilon \pi \tau v v \theta \varepsilon \dot{\varepsilon} v \tau \varepsilon \varsigma)$, and sprinkled over ( $\sigma \nu \mu \varphi v \rho \alpha \theta \varepsilon \dot{\varepsilon} v \varepsilon \varsigma)$ by the patience of the Word of God, and set on fire ( $\pi \nu \rho \omega \theta \varepsilon \dot{\varepsilon} \tau \varepsilon \varsigma$ ), they may be fitted for the royal banquet ( $\varepsilon \dot{v} \omega \chi i \alpha v)$. As a certain man of ours said, when he was condemned to the wild beasts because of his testimony with respect to God: «I am the wheat of Christ, and am ground by the teeth of the wild beasts, that I may be found the pure bread of God»".

${ }^{55}$ See also: Is $1: 25$; Jer 6:30; 9:6; Ps 16:3; 65,12; Wis 3:6; Prov 17:3; Job 23:10. 
from the technical term for fiery execution. Pionius, who wishes to convert pagans to Christianity, received the following response from his interlocutors:

"«You have no such power that we should be burnt alive (iv $\alpha \hat{\omega} v \tau \varepsilon \varepsilon$

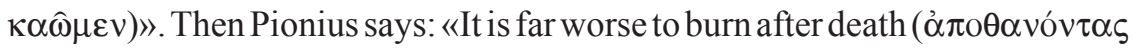
$\kappa \alpha v \theta \hat{\eta} v \alpha \mathrm{l}) »{ }^{n}{ }^{56}$.

Here we have a clear play on words between the participles $\zeta \hat{\omega} v \tau \varepsilon \varsigma$ and $\dot{\alpha} \pi 0 \theta \alpha$ óv $\tau \alpha \varsigma$, where the latter refers to the eschatological fire of Gehenna. Based on this wordplay, we can infer that the author of Martyrium Pionii interpreted the participle $\zeta \hat{\omega} v$ as semantically closer to "living" than "alive". In his final conversation with the proconsul, directly before the execution, Pionius

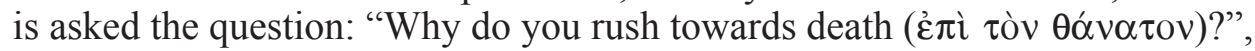

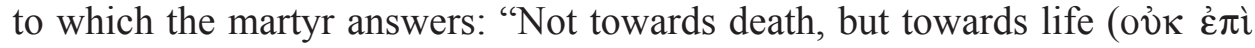

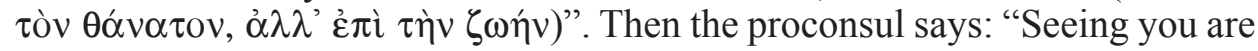

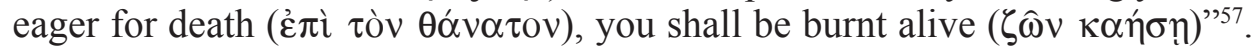
Again, a play on words takes place: the participle $\zeta \hat{\omega} v$ in the expression $\zeta \hat{\omega} v$

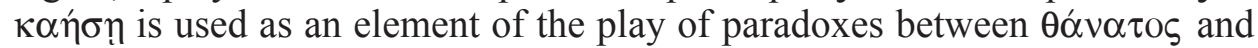
$\zeta \omega \eta$. Here we should understand that $\zeta \hat{\omega} \nu \kappa \alpha \eta ் \eta n$ signifies the final scene of the martyrium. After the fire goes out, the Christians, gathered around the pyre, see Pionius' body as the body of a beautiful ephebe-athlete ${ }^{58}$, which represents the actualization of his eschatological victory: "Indeed his crown

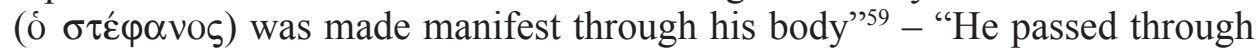

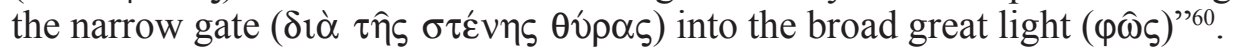

The ancient Christians perceived martyrdom not only as a perfect "dying of the grain", as "the narrow gate" or as a "birth", but also as a concrete manifestation of the reality of salvation here on earth. In the passages quoted above, we see how the Christian authors selected from the images provided to them by Holy Scripture everything that "positively" corresponded to the gloomy reality of the torture inflicted on them. The material gathered here may supplement the obvious answer to the question why in fact martyrdom was considered the ideal of Christian holiness. Besides this that the suffering and death of the martyr was the most perfect proof of love and fidelity to Christ, the torment to which previously imprisoned Christians were often subjected, whether of burning at the stake, or of spectacular venationes, pulled together an accumulation of paradoxical theophanic elements. One simply had to have

\footnotetext{
${ }^{56}$ Martyrium Pionii 7, 4, ed. and transl. Musurillo, p. 144-145.

${ }^{57}$ Ibidem 20, 5-6, ed. and transl. Musurillo, p. 162-163.

${ }^{58}$ Cf. ibidem 22, 2-4, ed. and transl. Musurillo, p. 164-165.

${ }^{59}$ Ibidem 22, 2, ed. and transl. Musurillo, p. 164-165.

${ }^{60}$ Ibidem 22, 1, Musurillo, p. 164-165.
} 
"eyes to see" ${ }^{\text {"61 }}$ that the soul saturated with images from Holy Scripture saw "in positive" what torment materially accumulated "in negative". This conclusion may shed some light on the formation of this ideal of holiness in the first three centuries of Christianity.

\section{ORNAMENTA SUNT ISTA NON VINCULA \\ - PARADOKSALNE PRZEWARTOŚCIOWANIE NARZĘDZI TORTUR WE WCZESNOCHRZEŚCIJAŃSKICH PISMACH O MĘCZEŃSTWIE}

(Streszczenie)

Zgodnie z teologią Nowego Testamentu śmierć chrześcijanina jest przejściem do życia wiecznego. Więcej, sam proces umierania, w myśl ewangelicznej dynamiki obumierania ziarna, jest rodzeniem się do nowego życia. Autorzy wczesnochrześcijańskiej literatury męczeńskiej mieli świadomość tego paradoksu. Już jej pobieżna lektura uzmysławia, jak wielką przykładali do niego wagę: nie tylko śmierć męczennika, ale także narzędzia kaźni, jakiej zostaje poddany, stają się już tu na ziemi objawieniem rzeczywistości zbawienia. Celem niniejszego artykułu jest wynotowanie i uporządkowanie tych miejsc z wczesnochrześcijańskiej literatury męczeńskiej, gdzie mamy do czynienia $\mathrm{z}$ owym paradoksalnym przewartościowaniem (podział na: więzienie, venationes, spalenie na stosie) oraz zestawienie ich z odpowiadającymi im miejscami z Pisma Świętego.

Key words: martyrdom, tortures, acta martyrum, Christian paradox, eternal life.

Słowa kluczowe: męczeństwo, tortury, acta martyrum, chrześcijański paradoks, życie wieczne.

${ }^{61}$ Martyrium Polycarpi 15, 1, ed. Dehandschutter, p. 18, transl. Hartog, p. 261: “And when

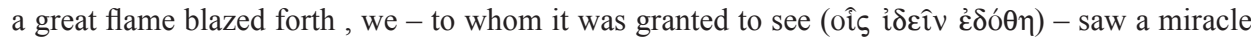

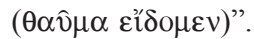

